\title{
Syncope mint a SARS-CoV-2-fertőzés egyedüli tünete
}

\author{
Arabadzisz Hrisula dr. - Tako Katalin dr. - Tomcsányi János dr. \\ Budai Irgalmasrendi Kórház, Kardiológia, Budapest
}

Egy 61 éves, SARS-CoV-2-fertőzött, traumás syncopés nóbeteg rosszullétének hátterében orthostaticus hypotonia igazolódott. A vírusfertőzés megszúnése után az orthostaticus hypotonia megszúnt, de a posturalis tachycardia fennmaradt. A syncopénak egyéb okát kimutatni nem tudtuk. A SARS-CoV-2-fertőzésnek egyéb tünete, illetve szervi manifesztációja nem volt. Tudomásunk szerint ez az első eset, amelyben a SARS-CoV-2-infekció egyedüli tünete a syncope.

Orv Hetil. 2021; 162(7): 243-245.

Kulcsszavak: syncope, orthostaticus hypotonia, posturalis tachycardia, SARS-CoV-2-infekció

\section{Syncope as the only symptom of SARS-CoV-2 infection}

Orthostatic hypotension was demonstrated in the background of malaise in a 61-year-old SARS-CoV-2 infected female traumatic syncope. After cessation of the virus infection, orthostatic hypotension resolved, but postural tachycardia persisted. No other cause of syncope could be detected. There were no other symptoms or organ manifestations of SARS-CoC-2 infection. To our knowledge, this is the first case where the only symptom of SARS-CoV-2 virus infection is syncope.

Keywords: syncope, orthostatic hypotension, postural tachycardia, SARS-CoV-2 infection

Arabadzisz H, Tako K, Tomcsányi J. [Syncope as the only symptom of SARS-CoV-2 infection]. Orv Hetil. 2021; 162(7): 243-245.

(Beérkezett: 2020. december 19.; elfogadva: 2020. december 29.)

\section{Rövidítések}

COVID-19 = (coronavirus disease 2019) koronavírus-betegség 2019; CT = (computed tomography) számítógépes tomográfia; $\mathrm{EKG}=$ elektrokardiográfia $; \mathrm{PCR}=$ (polymerase chain reaction) polimeráz-láncreakció; POT = posturalis tachycardia; RT-PCR = (real-time polymerase chain reaction) valós idejü polimeráz-láncreakció; SARS-CoV-2 = (severe acute respiratory syndrome coronavirus 2) súlyos akut légúti tünetegyüttest okozó koronavírus-2

A SARS-CoV-2-fertőzés felismerésének legalapvetőbb és legszélesebb körben elterjedt diagnosztikus módszere a valós idejü polimeráz-láncreakciós (RT-PCR) teszt [1]. Ennek segítségével olyan tünetek hátterében is kiderülhet a fertőzés, amelyek nem jellemzők erre az infekcióra. Ezen tünetek közé tartoznak a gyakran furcsa, neurogén szimptómák. A következő esetismertetésben is egy ilyen, SARS-CoV-2-fertőzés indukálta neurokardiogén tünet kerül bemutatásra.

\section{Esetismertetés}

A 61 éves egészségügyi dolgozó gyógyszert nem szed, munkájával jár a rendszeres fizikai aktivitás (gyógytornász), de syncope/praesyncope sohasem volt. Anamnézisében szövődménymentes szülések, traumás csuklófraktúrán kívül egyéb betegség nem szerepel. Panaszai a villamoson kezdődtek, ahol émelygés, rossz közérzet, szívdobogásérzés jelentkezett ülve, majd felállt, leszállt a villamosról, és a járdán eszméletét vesztette, fejsérüléssel. Tudata prompt visszatért. Osztályunkra a traumatológiai ellátás után negatív koponya-CT-vel érkezett a syncope 
további kivizsgálására. A trauma okozta fejfájáson kívül egyéb panasza, tünete, láza nem volt, normotenziós volt. Fizikális eltérést nem találtunk. Laboreredményei nem mutattak kóros eltérést. Az EKG-n sinusrhythmus, normális ingerületvezetés és repolarizáció volt . Az echokardiográfia hártyás billentyúket és strukturálisan ép szívet mutatott. Carotismasszázsra fiziológiás sinuslassulás következett be. A 24 órás monitorozás rhythmusszavart nem igazolt. Kétirányú mellkasröntgenje negatív lett. A carotismasszázs kóros eltérést nem mutatott. Schellongtesztje több mint $50 \mathrm{Hgmm}$-es tensioesésével erősen po- zitív lett (1. ábra). A beteget posturalis orthostaticus tachycardia okozta syncope diagnózisával bocsátottuk otthonába. Mivel azonban más, COVID-19-betegeket ellátó kórház zsúfolt traumatológiájáról vettük át, SARSCoV-2-PCR-tesztet végeztünk, amely pozitív lett. A beteg az otthonában 2 hét karanténba került úgy, hogy egyéb, a SARS-CoV-2-fertőzésre jellemző panasza és később tünete sem jelentkezett. Tizenhat nappal később, negatív PCR-teszt után ismét elvégzett Schellong-tesztje tensioesést nem igazolt, de a posturalis tachycardia (POT) frekvenciaválasza megmaradt (2. ábra).

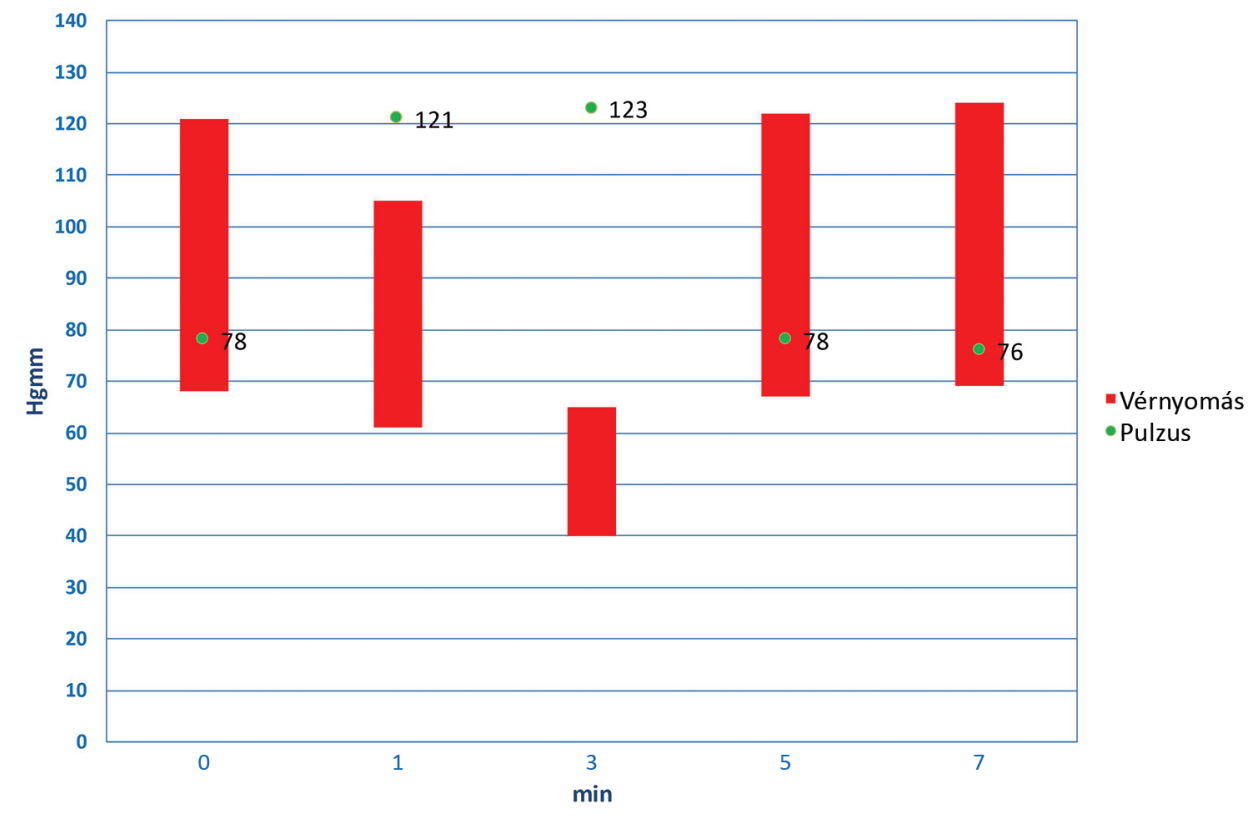

1. ábra | Shellong-teszt hatására bekövetkező vérnyomás- és pulzusváltozások a SARS-CoV-2-fertőzés alatt

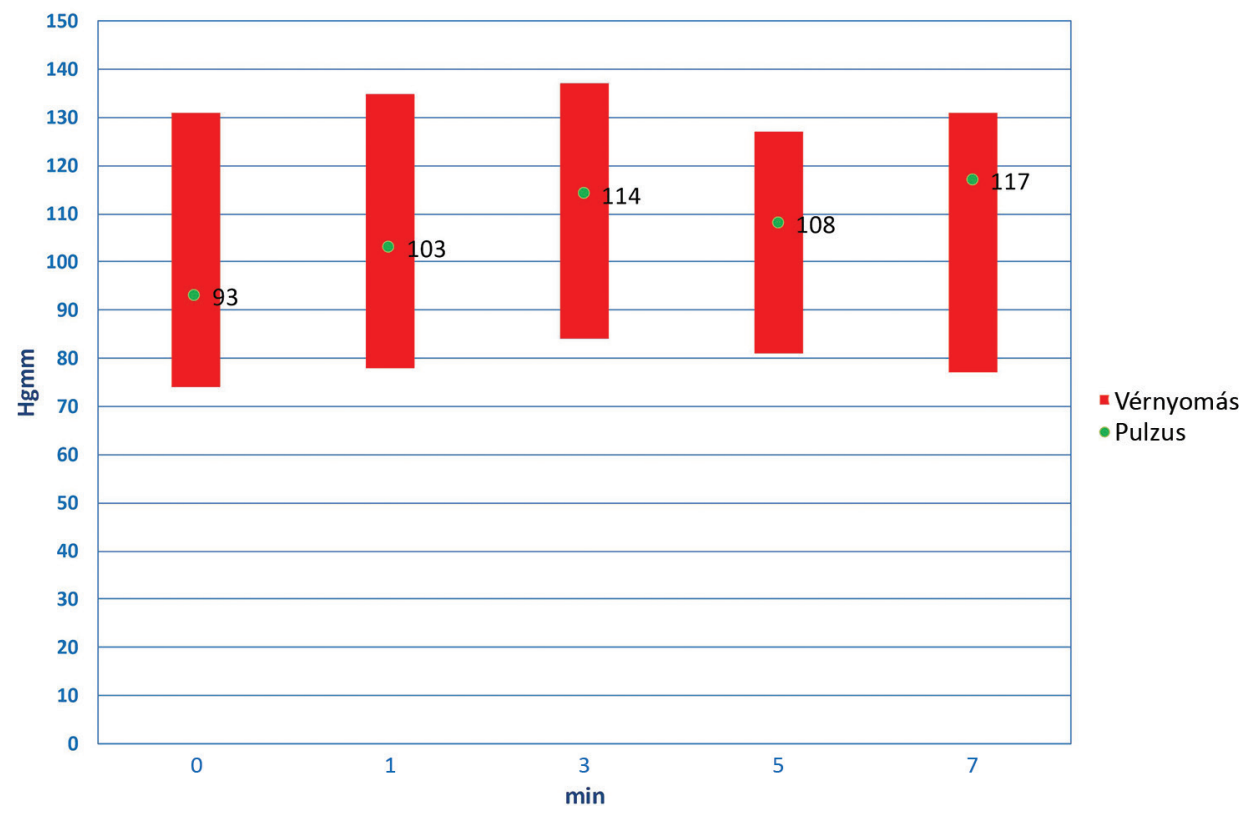

2. ábra | SARS-CoV-2-fertőzés után a Shellong-teszt hatására tensioesés már nem következett be, de a tachycardia perzisztált 


\section{Megbeszélés}

A SARS-CoV-2-infekció elsődlegesen akut respiratorikus betegség formájában jelentkezik, láz, köhögés, torokfájás, gyengeség képében. Emellett növekszik a cardiovascularis és neurológiai tüneteket produkáló esetek száma. A SARS-CoV-2-infekcióhoz társuló neurológiai manifesztációk három csoportba oszthatók: a centrális idegrendszer érintettségére utaló tünetek (ataxia, szédülés, eszméletvesztés, fejfájás, akut cerebrovascularis laesiók), perifériás idegrendszeri manifesztációk (szagló-, ízérzészavar, látási problémák, idegfájdalom), illetve musculoskeletalis manifesztációk [2]. A syncopét és a POT-ot mint a SARS-CoV-2-fertőzés tünetét több, napjainkban megjelent esetismertetés diszkutálja, az eddigi közlemények azonban mind a súlyos betegség egyik tüneteként ismertetik [3-5]. Esetünk bemutatását azért tartottuk fontosnak, mert tudomásunk szerint olyan syncopés eset nem volt, amelynél egyedüli tünetként ez az autonóm diszreguláció jelentkezett volna - kezdetben orthostaticus hypotonia kiváltotta syncope formájában, később pedig, a posturalis időszakban, syncope és tensioesés nélküli POT formájában. Ez utóbbit mint posturalis tünetet egy súlyos eset kapcsán már leírták. A patomechanizmust tekintve több tényező együttes szerepe valószínüsíthető, amelyek közül a neuroinflammatorikus tényezők okozta autonóm diszfunkció tűnik a legfontosabbnak [6]. Összefoglalva: napjainkban syncope esetén is kell a SARS-CoV-2-fertőzésre gondolni abban az esetben, ha a betegnél pozitív a Schellong-teszt, vagy POTszindrómája van.

(A betegnél a tachycardiás frekvenciaválasz további vizsgálatára billenőágyas tesztet terveztünk, amelyet azonban a járvány miatt egyelőre nem tudtunk kivitelezni.)
Anyagi támogatás: A közlemény megírása anyagi támogatásban nem részesült.

Szerzôi munkamegosztás: A. H.: A beteg kezelése és a cikk írása. T. K.: A beteg kezelése. T. J.: A cikk írása és az ábrák készítése. A cikk végleges változatát mindegyik szerző elolvasta és jóváhagyta.

Érdekeltségek: A szerzőknek a cikk írása kapcsán anyagi érdekeltségük nem volt.

\section{Irodalom}

[1] Korsós A, Kupcsulik Sz, Lovas A, et al. Diagnostic consideration and bedside estimation of the prognosis in COVID-19 patients. [Diagnosztikus lépések és a betegség prognózisának becslése COVID-19-fertőzött betegeken.] Orv Hetil. 2020; 161: 667671. [Hungarian]

[2] Mao L, Jin H, Wang M, et al. Neurologic manifestations of hospitalized patients with coronavirus disease 2019 in Wuhan, China. JAMA Neurol. 2020; 77: 683-690.

[3] Chen T, Hanna J, Walsh EE, et al. Syncope, near syncope or nonmechanical falls as a presenting feature of COVID-19. Ann Emerg Med. 2020; 76: 115-117.

[4] Oates C, Turagam MK, Musikantow D, et al. Syncope and presyncope in patients with COVID-19. Pacing Clin Electrophysiol. 2020; 43: 1139-1148.

[5] Ebrille E, Lucciola T, Amellone C, et al. Syncope as the presenting symptom of COVID-19 infection. HeartRhythm Case Rep. 2020; 6: 363-366.

[6] Goldstein DS. The extended autonomic system, dyshomeostasis, and COVID-19. Clin Auton Res. 2020; 30: 299-315.

(Arabadzisz Hrisula dr., Budapest, Árpád fejedelem útja 7., 1023 e-mail: harabadzisz@gmail.com)

\section{"Sero in periclis est consilium quaerere." (Veszély közepette késő tanácsot kérni.)}

